\title{
Population dynamics and production of Phyllorhiza punctata (Cnidaria: Scyphozoa) in Laguna Joyuda, Puerto Rico
}

\author{
Jorge R. García \\ Center for Energy and Environment Research, University of Puerto Rico, Mayaguez, Puerto Rico 00708, USA
}

\begin{abstract}
Medusae of Phyllorhiza punctata were sampled in Laguna Joyuda from October 1985 through October 1986. Maximum numerical abundance (143 ind per $10^{3} \mathrm{~m}^{3}$ ) and population biomass (530.6 $\mathrm{mg}$ ash-free dry wt [AFDW] $\mathrm{m}^{-3}$ ) were observed during summer Net increments in population. biomass were associated with growth of individuals from October to December and with individual growth and subsequent recruitment of small medusae from May to August. More than $75^{\circ}$. of the total recruitment into the smallest size classes $(<3 \mathrm{~cm})$ occurred in June, indicative of one large cohort from which most of the summer population developed. High mortality was observed after December 1985 , and between August and October 1986. Recruitment of the smaller medusae by early summer and mortality of large adults $(>30 \mathrm{~cm})$ during late summer in the following year suggests that $P$. punctata follows an annual cycle in Laguna Joyuda. Growth rates, calculated from increases in mean individual weight of field-collected specimens, were exponential during autumn (mean $\mathrm{g}_{\mathrm{w}}=0.077 \mathrm{~d}^{-1}$ ), and from June through August (summer; mean $g_{w}=0.079 \mathrm{~d}^{-1}$ ). Individual growth rates declined with increasing size during both these growth stanzas, but faster growth rates were observed in autumn for medusae of equivalent or larger size. Total population biomass increased exponentially at rates of ca 0.063 and $0.028 d^{-1}$ during October to December 1985 and May to August 1986 respectively. The slower growth rates in summer coincided with a marked reduction in abundance of non-gelatinous zooplankton, suggesting that medusae could have been food limited at this time. Nevertheless, estimated population production rates were much higher during summer (maximum $14.3 \mathrm{mg} \mathrm{AFDW} \mathrm{m}^{-3} \mathrm{~d}^{-1}$ ) due to the higher population biomass compared to autumn (maximum $1.6 \mathrm{mg} \mathrm{AFDW} \mathrm{m}^{-3} \mathrm{~d}^{-1}$ ).
\end{abstract}

\section{INTRODUCTION}

Several studies have characterized the population dynamics and production of aposymbiotic scyphomedusae, such as Aurelia aurita (Yasuda 1971, Hamner \& Jenssen 1974, Moller 1980, Van Der Veer \& Oorthuysen 1985, Papathanassiou et al. 1987, Gröndahl 1988). Production by $A$. aurita is greatest during the summer and appears to depend on the availability of zooplankton food, including egg-yolk fish larvae (Yasuda 1971, Moller 1980b, Purcell et al. 1987) and other planktonic cnidarians (Arai \& Jacobs 1980). Predation by scyphomedusae can regulate system function by releasing herbivore grazing pressure, thereby inducing phytoplankton blooms (Huntley \& Hobson 1978, Lindahl \& Hernroth 1983). In highly productive systems, such as Elefsis Bay, Greece (Papathanassiou et al. 1987) and Kiel Bight, Germany (Moller 1980) the population biomass of $A$. aurita has been shown to increase exponentially for at least 2 mo. Starvation, parasitism, predation and genetic determination have been proposed as potential causes for the typical population decline of $A$. aurita at the end of summer (Hamner \& Jenssen 1974, Möller 1980b).

Symbiosis is prevalent among tropical scyphomedusae of the Order Rhizostomae, examples being Mastigias spp., Cassiopea spp., and Phyllorhiza spp. (Mayer 1910). Algal endosymbionts (zooxanthellae) accelerate the excretion process of their hosts by utilization of ammonium-rich animal wastes (Younge \& Nicholls 1931, Muscatine 1971, Cates \& McLaughlin 1976), and contribute to the energetic requirements of the host by direct transfer of algal photosynthates (Hofmann \& Kremer 1981). The ecological implications of symbiotic medusae in coastal environments are poorly understood. In contrast to aposymbiotic medusae, symbiotic Cassiopea spp. and Mastigias sp. display net uptake and incorporation of ammonium-N from the 
water (Cates \& McLaughlin 1976, Muscatine \& Marian 1982). Mastigias sp. is believed to have little predatory impact upon zooplankton, and co-ocurrs with the zooplanktivorous Aurelia in salt-water lakes of Palau, Western Caroline Islands (Hamner \& Hauri 1981).

Information about population dynamics and production by symbiotic scyphozoans in tropical estuaries is lacking. In this study, I provide a basic characterization of the population growth dynamics and production by Phyllorhiza punctata von Lendenfeld, from Laguna Joyuda, Puerto Rico.

\section{METHODS}

Study site. Laguna Joyuda is a relatively small $\left(1.2 \mathrm{~km}^{2}\right)$, microtidal system located on the southwestern (Caribbean) coast of Puerto Rico $\left(18^{\circ} 07^{\prime} \mathrm{N}_{i} 67^{\circ}\right.$ $\left.11^{\prime} \mathrm{W}\right)$. A conspicuous band of red mangrove Rhizophora mangle borders the lagoon. Average depth is $1.3 \mathrm{~m}$ ( $\max .3 .0 \mathrm{~m}$ ). Water exchange between the lagoon and the sea occurs along a single channel $(0.5 \mathrm{~km}$ long). Preliminary studies on the hydrology of the lagoon indicate that the average flushing time due to the tidal effect is on the order of 1 mo (U.S. Geological Survey unpubl.). Salinity is relatively uniform

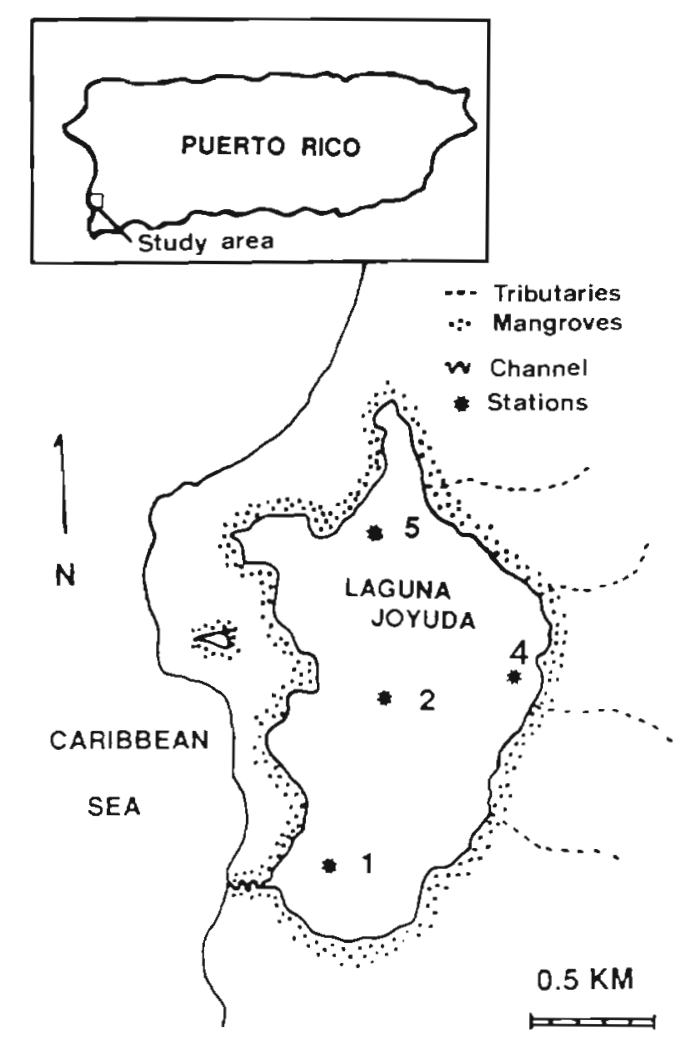

Fig. 1. Location of sampling stations at Laguna Joyuda throughout the lagoon but varies with rainfall and ranges from 10 to $35 \mathrm{ppt}$. Water temperature varies annually between 24 and $32^{\circ} \mathrm{C}$.

Sampling. Locations of sampling stations are shown in Fig. 1. Only individuals in the medusa stage, with a bell diameter of $>0.5 \mathrm{~cm}$, were included in this study. Scyphomedusae were sampled with a $0.4 \mathrm{~cm}$ mesh nylon beach seine (30.5 $\mathrm{m}$ length; $2.7 \mathrm{~m}$ high), hauled with two $61 \mathrm{~m}$ long nylon ropes. The total seined area (ca $1333 \mathrm{~m}^{2}$ ) was multiplied by the average station depth to obtain the total $\mathrm{m}^{3}$ sampled. Generally, 2 hauls were taken at Stns 1, 2, 4 and 5 on each sampling date, except during the period of high abundance in summer when only 3 stations were sampled. The bell diameter of each medusa individual was measured in the field to the nearest $0.5 \mathrm{~cm}$. Specimens of various sizes $(\mathrm{n}=32)$ were rinsed with distilled water, oven-dried at $60^{\circ} \mathrm{C}$ for $3 \mathrm{~d}$ and then ashed in a muffle furnace $\left(500^{\circ} \mathrm{C}\right)$ to obtain a bell diameter (L) to ash-free dry weight (AFDW) relationship. Weight of individuals and population biomass determinations were calculated from this relationship. Zooplankton was collected at Stns 1 , 2,4 and 5 with a gasoline-driven on-deck pump (mean flow ca $0.85 \mathrm{~m}^{3} \mathrm{~min}^{-1}$ ). Animals were retained in a 64 um mesh net and preserved in a $3 \%$ buffered formalin and lagoon water solution.

A 2-way analysis of variance (Sokal \& Rolf 1969) was used to test differences in abundance between stations and dates. Lloyd's (1967) 'mean crowdiness index' was used to examine spatial dispersion patterns during each sampling date. The mean crowding ( $\mathrm{m}$ *) to sample mean $(m)$ ratio approaches unity $(1.0)$ in randomly distributed cases, while values above unity are representative of aggregated (patchy) distributions. After Lloyd (1967):

$$
\mathrm{m} \cdot=\mathrm{m}+\left[\left(\mathrm{s}^{2} / \mathrm{m}\right)-1\right]
$$

where $\mathrm{m}$ and $\mathrm{s}=$ sample mean and standard deviation of abundance from stations sampled on each date.

Size distributions of the medusa population were based on $2 \mathrm{~cm}$ intervals of bell diameter. Normality of size distributions was tested using the Shapiro-Wilk test (Shapiro et al. 1968). The arithmetic mean bell diameter was used for growth determinations of normal size distributions. When size distributions deviated significantly from normality $(p<0.05)$ an attempt was made to identify the main cohorts in the population with normal size distributions. Separation of normal components (cohorts) from populations with non-normal size distributions followed a modification of the Bhattacharya (1967) method proposed by Pauly \& Caddy (1985). Following the Pauly \& Caddy (1985) procedure, the natural logarithms of the ratios of successive size frequencies $\left[\log _{e}\left(f_{i+1} / f_{i}\right)\right]$ plotted against the midpoints of the corresponding size classes $\left(\mathrm{x}_{\mathrm{i}}\right)$ 
define straight lines when the distributions are normal. Straight lines are of the form:

$$
F_{1}=a+b x_{l}
$$

where $F_{i}=\log _{e}\left(f_{i+1} / f_{i}\right)$, and the slope $(b)$ has a negative sign. When a straight line was identified ( $\mathrm{r}$ significant at $p<0.05$ ) and its parameters ( $a$ and $b$ ) estimated by linear regression, the mean size $(\mu)$ and standard deviation (s) of the cohort were obtained from:

and

$$
\mu=(0.5 d)-(a / b)
$$

$$
s=\left[-1 / b-\left(d^{2} / 12\right)\right]
$$

where $d=$ size class interval; $a$ and $b=y$ intercept and slope of the line, respectively. The number of individuals in each cohort was approximated by $\mu \pm 2 \mathrm{~s}$. The mean size of the principal summer cohort was used in growth determinations and estimates of production by that cohort.

Estimates of secondary production by Phyllorhiza punctata were attempted during periods when successive increments in individual growth and population biomass were evident. The general procedure for estimation of secondary production proposed by Kimmerer (1987) was adopted with minor modifications. Following this method, mortality need not be considered and integrated production (IP) can be determined from sample data on production rate (PR). Instead of assigning variable growth rates to different life stages, or subpopulations (sensu Kimmerer 1987), I considered only one cohort in the population after testing for normality in size distribution. Then, after Kimmerer (1987):

$$
P R=\sum g_{i} B_{1}
$$

where PR is an estimate of the 'instantaneous' produc-

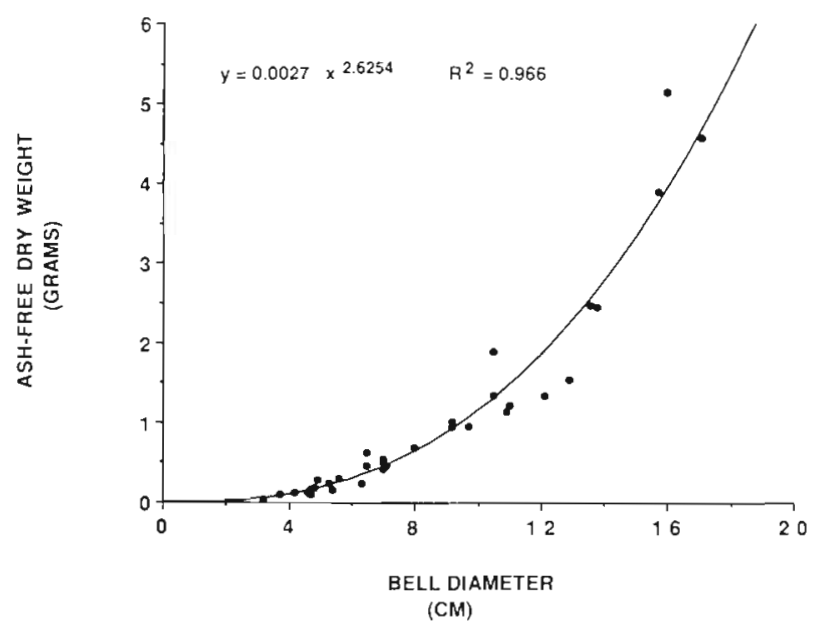

Fig. 2. Phyllorhiza punctata. Relationship between bell diameter and ash-free dry weight of field-collected medusae tion rate ( $m$ g AFDW $\mathrm{m}^{-3} \mathrm{~d}^{-1}$ ), in practice estimated over a discrete time interval $i$. The parameter i represents different time intervals during which a discrete cohort was identified. B was the arithmetic mean population biomass during the $i^{\text {th }}$ sampling interval (mg AFDW $\mathrm{m}^{-3}$ ). The mean instantaneous cohort growth rate $g_{w}\left(\mathrm{~g} \mathrm{~d}^{-1}\right)$, was estimated from the rate of individual biomass increase per day calculated according to:

$$
W_{i}=W_{1-1} e^{i g i) t}
$$

where $W_{1,1-1}=$ mean individual weights during the $i^{\text {th }}$ sampling interval; $\mathrm{t}=1 \mathrm{~d}$.

The total cohort production rate was calculated according to:

$$
I P_{2}=\int_{t_{1}}^{t_{2}} P R_{1} T
$$

where $\mathrm{IP}_{2}=$ production rate integrated over the time period $t_{1}, t_{2} ; T=$ duration of the sampling interval (d).

\section{RESULTS}

\section{Medusa length-weight relationships}

The relationship between bell diameter (L) and ashfree dry weight (AFDW) was exponential for medusa individuals in the size range between 3.0 and $17.0 \mathrm{~cm}$ (Fig. 2). From this relationship, AFDW (g) $=0.0027$ $\mathrm{L}^{2.6254}$. AFDW was on average $33.6 \% \quad(0.336 \pm 0.052$ SD, $n=31$ ) of dry weight.

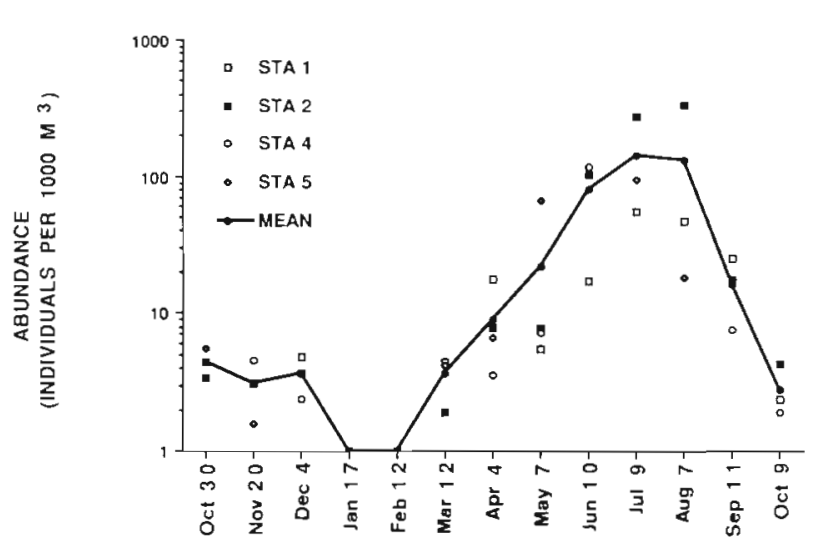

Fig. 3. Phylloriza punctata. Temporal and spatial variability in abundance of medusae at Laguna Joyuda (Oct 1985-86). Values for each station represent the mean abundance from 2 samples taken at each station 


\section{Seasonal and spatial abundance pattern}

Fig. 3 shows the temporal pattern of medusa abundance from samplings at 3 (sometimes 4) stations in the lagoon. Abundance during autumn (30 Oct to 4 Dec 1985) was relatively low $\left(<5\right.$ ind. per $\left.10^{3} \mathrm{~m}^{3}\right)$ and without detectable change in magnitude (within $95 \%$ confidence limits). After 4 December, abundance of individuals declined sharply, and after 18 December no individuals were observed again until March. It is uncertain if the component of very large individuals which reappeared during April ever left the lagoon, or if they were missed from collections due to an unusual spatial distribution. A sustained increase in abundance resulted in samplings from March through July, reaching a peak mean abundance of 143 ind. per $10^{3} \mathrm{~m}^{3}$. Abundance remained high in August, and then declined during September to a minimum of $<2$ ind. per $10^{3} \mathrm{~m}^{3}$ in October. Maximum abundance of medusa in a single haul was recorded at $\operatorname{Stn} 2$ in August (437 ind. per $10^{3} \mathrm{~m}^{3}$ ).

The mean coefficient of variation from replicate collections at Stns 1, 2, 4 and 5 was $48 \%$ (within station), and $76 \%$ between stations. A 2-way analysis of variance (ANOVA) showed that there was a highly significant ( $p<0.001$ ) interaction effect between stations and dates, meaning that differences between stations depend upon season. Differences between stations were more pronounced during the summer (May through August) when abundances were higher (Fig. 3). Lloyd's (1967) 'mean crowdiness' index ranged from 1.4 to 2.3 during the summer season, suggesting aggregated, or 'patchy' distribution patterns. Values lower than or close to unity ( 0.8 to 1.3$)$ prevailed during autumn, suggesting a more random distribution between stations. Abundance values at Stn 2 were at least 3 times higher than at any other sampling station during July and August.

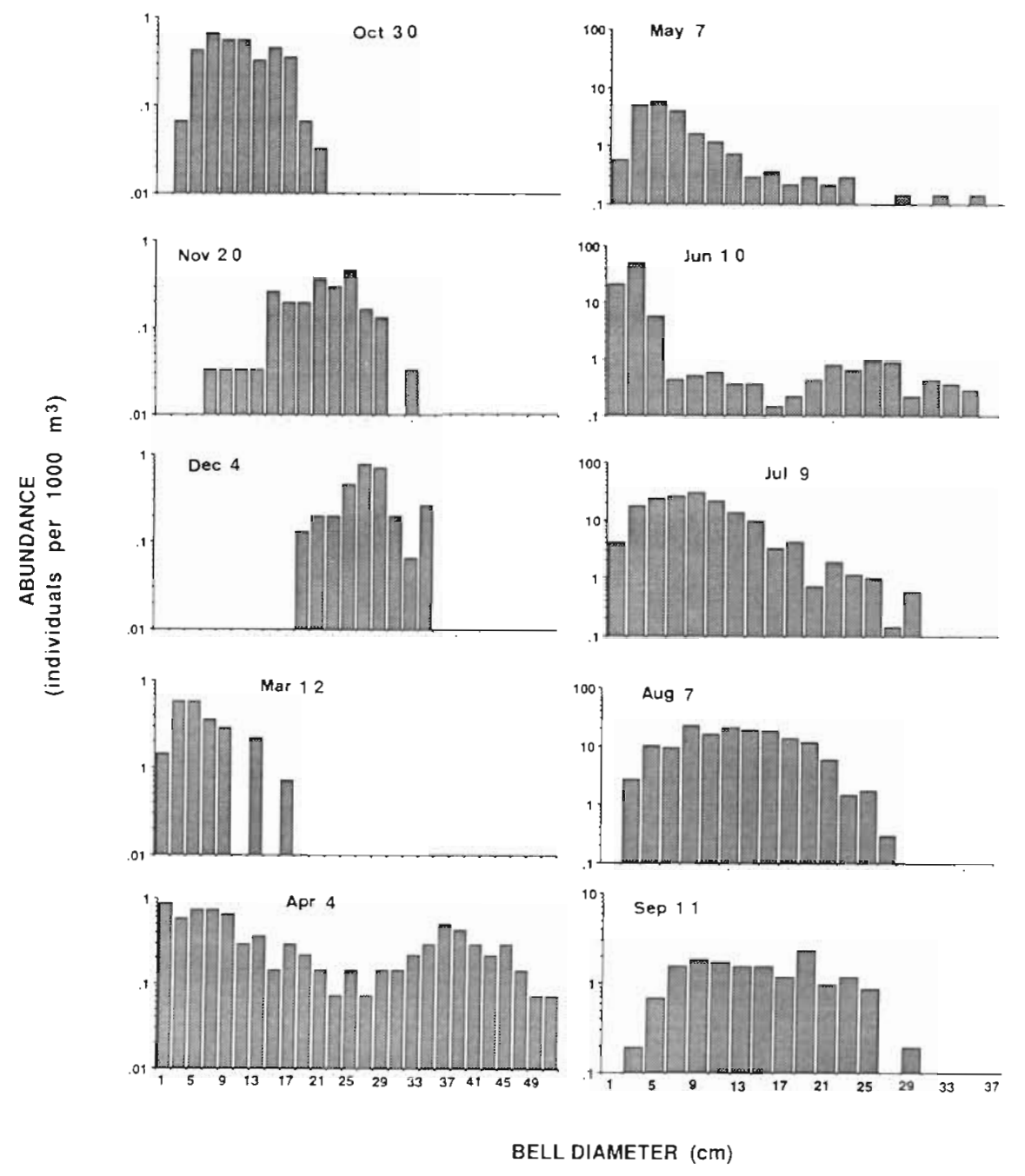

Fig. 4. Phyllorhiza punctata. Size-frequency distributions of medusae from field collections at Laguna Joyuda (Oct 85-86). Note differences in logarithmic scale of abundance during the summer period 
Seasonal changes in mean size and individual growth rates

Large individuals were the most abundant size group observed from October through December 1985 (Fig. 4). Based on the size distributions, there was no indication of recruitment by small medusae $(<3 \mathrm{~cm})$ during this period. The numerical abundance of individuals remained constant and the mean bell diameter increased from $10.1 \mathrm{~cm}$ on 30 October to $26.9 \mathrm{~cm}$ on 4 December 1985. Table 1 gives descriptive statistics of the size distributions of medusae during the study period. Initial recruitment of small meduse was observed during March (Fig. 4), but abundance was relatively low. The population size distribution in April was characterized by an increase in recruitment of juvenile medusae $(<3 \mathrm{~cm})$, relatively low abundance of intermediate sizes, and also by the presence of very large medusae. The abundance of these very large medusae was similar to the abundance of the populations present during autumn (October to December 1985), but the size range was relatively larger in April. These very large individuals $(>30 \mathrm{~cm})$ persisted until July. Significant deviations from normality $(p<0.05$ ) in size distributions of medusae were observed during the period between May and July (Table 1).

A strong new cohort of juveniles in which medusae smaller than $3 \mathrm{~cm}$ represented ca $78 \%$ of the total was observed in June (Fig. 4). The population mean bell diameter was $4.8 \mathrm{~cm}$ in June due to the effect of the few very large medusae present. However, separation of normal components identified a cohort with a mean of $2.5 \mathrm{~cm}$ representing $84 \%$ of the total population num- bers, and 2 additional subpopulations, or cohorts, with means of 24.5 and $34.0 \mathrm{~cm}$. By July, ca $92 \%$ of the total individuals belonged to a single cohort with a mean of $8.5 \mathrm{~cm}$. The size of this cohort continued to increase during the summer reaching a mean bell diameter of $15.2 \mathrm{~cm}$ by September. No further significant increase in bell diameter was observed in October 1986. It should be noted that there was a marked decline in abundance of medusae in September and October at the time that growth rates slowed down.

The mean growth rates in weight (AFDW) of Phyllorhiza punctata individuals between October and December 1985, and June and September 1986, were 0.077 and $0.079 \mathrm{~d}^{-1}$. During both periods the instantaneous rates of individual growth declined with increasing size (Table 2). The larger medusae present during October to December had similar growth rates to smaller individuals present in summer. The highest instantaneous growth rate was observed during the 10 June to 9 July interval $\left(g_{w}=0.11 \mathrm{~d}^{-1}\right.$ ) when medusae increased in mean AFDW from 0.03 to $0.74 \mathrm{~g}$ (2.5 to $8.5 \mathrm{~cm}$ in bell diameter). The highest instantaneous growth rate during autumn was observed in the period from 30 October to 4 December $\left(g_{w}=0.096 d^{-1}\right)$, when medusae increased in mean AFDW from 1.17 to $8.0 \mathrm{~g}$ (10.1 to $21.0 \mathrm{~cm}$ in bell diameter).

\section{Changes in population biomass and production rate}

Two periods of growth in population biomass were observed, from 30 October to 4 December 1985 (autumn), and from May to October 1986 (summer)

Table 1. Phyllorhiza punctata. Size distribution statistics in Laguna Joyuda during October 1985-86

\begin{tabular}{|c|c|c|c|c|c|c|}
\hline $\begin{array}{l}\text { Dates } \\
(1985-86)\end{array}$ & $\begin{array}{l}\text { No. of inds. } \\
\text { measured }\end{array}$ & $\begin{array}{l}\text { Size distribution } \\
\text { normality test } \\
\text { (Shapiro et al. } \\
\text { 1968) p-value }\end{array}$ & $\begin{array}{l}\text { Population } \\
\text { mean bell } \\
\text { diam. }(\mathrm{cm})\end{array}$ & $\begin{array}{l}\text { Normal } \\
\text { components } \\
\text { mean bell } \\
\text { diam. }(\mathrm{cm})\end{array}$ & $\mathrm{SD}$ & $\begin{array}{l}\text { No. medusae } \\
\text { per component }\end{array}$ \\
\hline $30 \mathrm{Oct}$ & 107 & 0.412 & 10.1 & 10.1 & 4.2 & 107 \\
\hline $20 \mathrm{Nov}$ & 64 & 0.129 & 21.0 & 21.0 & 5.1 & 64 \\
\hline $4 \mathrm{Dec}$ & 47 & 0.11 & 26.9 & 26.9 & 3.8 & 47 \\
\hline $12 \mathrm{Mar}$ & 31 & 0.5 & 6.1 & 6.1 & 3.6 & 31 \\
\hline \multirow{2}{*}{$4 \mathrm{Apr}$} & 111 & $0.004^{\cdots}$ & 19.2 & 5.9 & 3.5 & 55 \\
\hline & & & & 38.4 & 4.4 & 40 \\
\hline 7 May & 296 & $0.001 \cdots$ & 7.6 & 4.6 & 1.8 & 204 \\
\hline \multirow[t]{3}{*}{$10 \mathrm{Jun}$} & 1191 & $0.001 \cdots$ & 4.8 & 2.5 & 1.0 & 1006 \\
\hline & & & & 24.4 & 2.7 & 56 \\
\hline & & & & 34.1 & 1.7 & 19 \\
\hline \multirow[t]{2}{*}{$9 \mathrm{Jul}$} & 1107 & $0.012^{\cdots}$ & 9.7 & 8.8 & 2.6 & 1017 \\
\hline & & & & 23.8 & 0.7 & 20 \\
\hline 7 Aug & 532 & 0.093 & 14.2 & 14.2 & 5.4 & 532 \\
\hline $11 \mathrm{Sep}$ & 162 & 0.652 & 15.2 & 15.2 & 6.0 & 162 \\
\hline 9 Oct & 19 & 0.274 & 16.3 & 16.3 & 7.0 & 19 \\
\hline
\end{tabular}


(Table 2). Biomass increased from 6.2 to $49.8 \mathrm{mg}$ AFDW $\mathrm{m}^{-3}$ during autumn, and from 43.6 to $530.6 \mathrm{mg}$ AFDW $\mathrm{m}^{-3}$ during summer. At these times, changes in population biomass appeared to be exponential, ca 0.063 and $0.027 \mathrm{~d}^{-1}$ for the corresponding periods of autumn and summer. Biomass increments during autumn resulted from growth of individuals since no detectable changes in abundance were observed. In April, biomass was relatively high due to the presence of large individuals in the population. These were replaced by smaller individuals in May resulting in a decline in biomass. Population biomass then increased consistently until reaching a peak in Augrust. Summer biomass increments were associated with recruitment of young medusae from March through July, and also with growth of individuals. The doubling in population biomass from July to August was conferred only by growth of individuals.

The estimated secondary production of Phyllorhiza punctata was much higher during the summer than in the autumn period (Table 2). Total integrated production during autumn (October through December) was estimated as $48.4 \mathrm{mg}$ AFDW $\mathrm{m}^{-3}$ compared to ca $696 \mathrm{mg}$ AFDW $\mathrm{m}^{-3}$ during summer. It must be noted that only the production of the principal summer cohort was considered. Although the rate of population biomass increase was higher during autumn, the production rate of the summer population was much higher due to the higher standing crops.

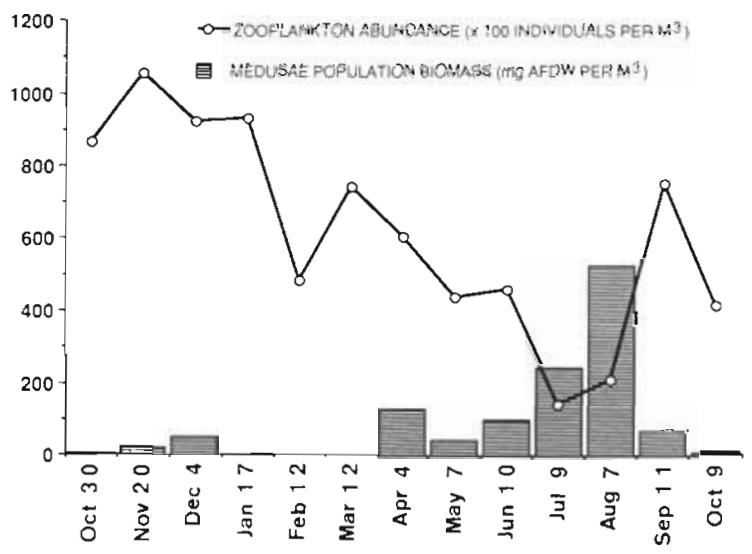

Fig. 5. Phyllorhiza punctata. Relationship between the temporal abundance pattern of total zooplankton ( $>64 \mu \mathrm{m})$ and the population biomass of medusae in Laguna Joyuda (Oct $85-86)$

\section{Seasonal changes in non-gelatinous zooplankton}

The calanoid copepod Acartia tonsa Dana, chaetognaths (Sagitta spp.), and meroplanktonic populations of polychaetes, decapods and cirripeds characterized the taxonomic composition of non-gelatinous zooplankton in Laguna Joyuda during the study period. Developmental stages and adults of $A$. tonsa represented more than $90 \%$ of the total individuals throughout the year (García \& López in press). Total zooplankton (> $64 \mathrm{~m}$ )

Table 2. Phyllorhiza punctata. Estimates of production by the dominant cohorts during autumn 1985 and summer 1986 in Laguna Joyuda

\begin{tabular}{|c|c|c|c|c|c|}
\hline $\begin{array}{l}\text { Dates } \\
(1985-86)\end{array}$ & $\begin{array}{l}\text { Mean population biomass } \\
\quad\left(\mathrm{mg} \mathrm{AFDW} \mathrm{m}^{-3}\right)\end{array}$ & 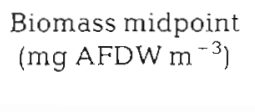 & $\underset{\left(d^{-1}\right)}{g_{w}}$ & $\begin{array}{c}\text { Production rate } \\
\text { (mg AFDW } \\
\left.\mathrm{m}^{-3} \mathrm{~d}^{-1}\right)\end{array}$ & $\begin{array}{c}\text { Integrated } \\
\text { production } \\
\left(\mathrm{mg} \mathrm{AFDW} \mathrm{m}^{-3}\right)\end{array}$ \\
\hline \multirow[t]{2}{*}{$30 \mathrm{Oct}$} & 6.2 & & & & \\
\hline & & 13.4 & 0.096 & 1.3 & 25.7 \\
\hline \multirow[t]{2}{*}{$20 \mathrm{Nov}$} & 20.6 & & & & \\
\hline & & 35.2 & 0.046 & 1.6 & 22.7 \\
\hline $4 \mathrm{Dec}$ & 49.8 & & & & \\
\hline $12 \mathrm{Mar}$ & 2.7 & & & & \\
\hline $4 \mathrm{Apr}$ & 8.1 & & & & \\
\hline 5 May & 21.3 & & & & \\
\hline \multirow[t]{2}{*}{$10 \mathrm{Jun}$} & $(3.6)^{\mathrm{a}}$ & & & & \\
\hline & $\left(13651^{\circ}\right.$ & 70.0 & 0.11 & 7.7 & 231.0 \\
\hline $9 \mathrm{Jul}$ & $(136.5)^{\circ}$ & 333.6 & 0.043 & 14.3 & 416.0 \\
\hline \multirow[t]{2}{*}{7 Aug } & 530.6 & & & & \\
\hline & & 298.8 & 0.005 & 1.5 & 49.3 \\
\hline $11 \mathrm{Sep}$ & 66.9 & & & & \\
\hline $90 c t$ & 9.3 & & & & \\
\hline
\end{tabular}


abundance varied between a maximum of 122717 ind $\mathrm{m}^{-3}$ in January and a minimum of 16427 ind. $\mathrm{m}^{-3}$ in July. Significant negative correlations between total zooplankton and abundance of scyphomedusae have been found (García \& López in press).

A marked decline in non-gelatinous zooplankton abundance was associated with the period of high population biomass of Phyllorhiza punctata during summer (Fig. 5). Total zooplankton abundance declined by a factor of 4 from May to August while the biomass of medusae increased by an order of magnitude. Zooplankton abundance then increased again in September after the drop of medusae biomass. In autumn, the abundance of zooplankton remained high and relatively constant despite the increasing pattern of medusae biomass. The summer decline in zooplankton abundance was associated with a period of significantly higher phytoplankton standing crops (chlorophyll a: 15 to $25 \mu \mathrm{g} \mathrm{l}^{-1}$ ) and productivity rates (0.6 to $\left.1.0 \mathrm{~g} \mathrm{C} \mathrm{m}^{-3} \mathrm{~d}^{-1}\right)$, relative to autumn and winter (García \& López in press). Chaetognaths, which represent potentially important predators of zooplankton, also declined in abundance during the summer.

\section{DISCUSSION}

Phyllorhiza punctata displayed a strong summer bloom in Laguna Joyuda. This is similar to observations reported elsewhere for the related Aurelia aurita (Hamner \& Jenssen 1974, Möller 1980, Van der Veer \& Oorthuysen 1985, Papathanassiou et al. 1987, Gröndahl 1988). However, in contrast to these observations where $A$. aurita is present for only part of the year, $P$. punctata appears to grow inside the lagoon throughout the year. Peak recruitment of young medusae in June and a gradual decline in abundance of full-grown individuals $(>30 \mathrm{~cm}$ ) until July suggests that this population follows an annual cycle. Although recruitment of juvenile medusae was observed from March through July, most of the summer population seems to have developed from a large cohort which appeared in June. Ephyras, the planktonic larvae that preceed the medusae stage, have been observed in the lagoon during April and May (García unpubl.), suggesting that recruitment into the medusae stage takes place inside the lagoon. The life cycle of $P$. punctata in Laguna Joyuda needs to be studied in more detail, since background information on the syphistomae (sedentary polyp) and ephyrae (planktonic larvae) stages is not presently available.

The spatial distribution of Phyllorhiza punctata showed that differences in abundance between stations were significant, but without any consistent pattern through time. Increased patchiness was evidenced during peak abundance in summer, with particularly high abundances at Stn 2 during July and August. Stn 2 is located on the western section of the lagoon. The prevailing wind from the southeast could influence the aggregations of medusae in the western section of the lagoon in summer. Also, this section of the lagoon is illuminated by the sun during the morning, when collections were made, raising the possibility that horizontal diel migrations in relation to sunlight play an important role in the spatial distribution of $P$. punctata as has been documented by Hamner \& Hauri (1981) for Mastigias sp. at Eil Malk Lake, Palau. At present, there is insufficient data to test these hypotheses.

Increases in mean weight of individuals continued during consecutive observations for at least $90 \mathrm{~d}$ during the summer and approximately 1 mo (34 d) from late October to December. During both periods the instantaneous rates of growth declined with increasing size of medusae. The larger medusae present at the beginning of the sampling period in autumn had similar growth rates to the small, newly recruited individuals present the following summer. Since the smaller individuals would normally be expected to have higher specific growth rates than larger ones, this would suggest that the small medusae of this large cohort were growing at less than maximal rates. These low growth rates of medusae during summer coincided with low zooplankton abundance suggesting food limitation. Given the high phytoplankton concentrations present at this time (García \& López in press), low zooplankton abundance also suggests that these medusae had a significant predatory impact upon zooplankton during this period. In contrast, zooplankton remained high during the period of autumn when the medusae population biomass was relatively low, perhaps reflecting the reduced impact of low predator density, and at the same time representing a richer food environment for the medusae population present.

Phyllorhiza punctata has been shown to have high levels of algal endosymbionts (zooxanthellae) (García \& Durbin unpubl.) and thus autotrophy may be important for this species. It is interesting to note that the growth of medusae during the autumn was preceeded by high runoff and a strong spike of ammonium in the water column during October, which declined gradually until December (López pers. comm.). There was another spike of dissolved inorganic nitrogen in May (Gracía \& López in press), but the dominant species was nitrate (López pers. comm.). Muscatine \& Marian (1982) have shown that Mastigias sp. removes and assimilates ammonium from the water but does not significantly affect the concentration of nitrate. Thus, it is also possible that the higher growth rates of medusae in autumn were fueled by the availability of ammonium and higher production by the symbiotic algae, in addi- 
tion to the higher zooplankton concentrations at this time. A more careful examination of the relative importance of heterotrophic vs autotrophic production in the growth dynamics of symbiotic scyphomedusae is critically needed to answer this question.

As was the case for individual growth, the grow th rate of population biomass was higher during the autumn, but population production was lower compared to the summer. Production by Phyllorhiza punctata in autumn was only associated with growth of individuals. This reflects differences in biomass present during the 2 periods. As suggested above, the production dynamics of $P$. punctata during summer could be a densitydependent phenomenon in which the medusae population grows to the point where zooplankton food and/or dissolved nutrient concentration becomes a limiting factor. At present there is insufficient data to confirm this hypothesis. Depletion of zooplankton foods by gelatinous predators has been previously reported (Huntley \& Hobson 1978, Deason \& Smayda 1982, Lindahl \& Hernroth 1983) and typically preceeds the population crash of aposymbiotic medusae and ctenophore populations during late summer in temperate systems. Direct transfer of algal production (photosynthates) to animal tissue has been shown for Cassiopea andromedea (Hofmann \& Kremer 1981), but it is insufficient to meet the nutritional demands of the growing scyphozoon. Both $C$. andromedea and P. punctata have the ability to remain at the bottom for extended periods of time; this may be a behavorial adaptation to optimize assimilation of benthic nutrient fluxes.

The growth rates in bell diameter of Phyllorhiza punctata during the first 2 summer months $(0.041$ and $0.018 \mathrm{~d}^{-1}$, June to Augustj fall in a similar range as those reported for Aurelia aurita $\left(0.028\right.$ to $0.038 \mathrm{~d}^{-1}$, Möller $1980 \mathrm{~b} ; 0.023$ to $0.04 \mathrm{~d}^{-1}$, Van der Veer \& Oorthuysen 1985; $0.032 \mathrm{~d}^{-1}$, Jasuda $1971 ; 0.023 \mathrm{~d}^{-1}$, Hamner \& Jenssen 1974). However, the ratio of dry weight to bell diameter in $P$. punctata is more than 3 times higher than in Aurelia aurita (García \& Durbin unpubl.). As a result, the increase in mean individual dry weight of $P$. punctata during a $60 \mathrm{~d}$ period from June to August $\left(0.09\right.$ to $8.51 \mathrm{~g}$ dry weight, or $\left.0.086 \mathrm{~d}^{-1}\right)$ is higher than any value reported in the literature for a scyphozoan in a 2 mo time span. The net increase in population biomass of $P$. punctata in Laguna Joyuda (16.1 $\mathrm{mg} \mathrm{d}$ wt $\mathrm{m}^{-3} \mathrm{~d}^{-1}$. May to August) falls between the 2 highest production records for $A$. aurita. From the data of Moller (1980b), population biomass increased from 40.5 to $707.0 \mathrm{mg} \mathrm{d} \mathrm{wt} \mathrm{m} \mathrm{m}^{-3}\left(7.4 \mathrm{mg} \mathrm{d} \mathrm{wt} \mathrm{m}^{-3} \mathrm{~d}^{-1}\right)$ in the Kiel Bight in 1979 during a $90 \mathrm{~d}$ interval. The highest reported rate of population biomass increase by a scyphomedusae (A. aurita) in a $90 \mathrm{~d}$ period (ca $30 \mathrm{mg}$ $\mathrm{d}$ wt $\mathrm{m}^{-3} \mathrm{~d}^{-1}$ ) is from Elefsis Bay, a highly eutrophic coastal system in Greece (Papathanassiou et al. 1987).
Acknowledgements. This work was partially supported by a grant from the National Science Foundation (EPSCoR Program) and the Center for Energy and Environment Research. Thanks are expressed to Drs Ted Durbin and Paul Yoshioka for their critical review of earlier versions of this manuscript. Mr Denis Corales and Carlos Bonafé served as field technicians during the sampling program.

\section{LITERATURE CITED}

Arai, M. N., Jacobs, R. J. (1980). Interspecific predation of common Strait of Georgia planktonic coelenterates: laboratory evidence. Can. J. Fish. Aquat. Sci. 37. 120-123

Bhattacharya, C. G. (1967). A simple method of resolution of a distribution into Gaussian components. Biometrics 23: $115-135$

Cates, N., McLaughlin, J. J. A. (1976). Differences of ammonia metabolism in symbiotic and aposymbiotic Condylactus and Cassiopeia spp. J. exp. mar. Biol. Ecol. 21: 1-5

Deason, E. E., Smayda, T. J. (1982). Ctenophore-zooplanktonphytoplankton interactions in Narragansett Bay. J. Plankton. Res. 4: 203-217

García, J. R., López, J. M. (in press). Seasonal patterns of phytoplankton productivity, zooplankton abundance and hydrological conditions in Laguna Joyuda, Puerto Rico Scient. Mar. 53 (2-3)

Gröndahl, F. (1988). A comparative study on the scyphozoans Aurelia aurita, Cyanea capillata, and C. lamarckii in the Gullmar Fjord, western Sweden. Mar Biol. 97: $541-550$

Hamner, W. M., Jenssen, R. M. (1974). Growth, degrowth, and irreversible cell differentiation in Aurelia aurita. Am. Zool. 14: $833-849$

Hamner, W. M., Hauri, I. (1981). Long-distance horizontal migrations of zooplankton (Scyphomedusae: Mastigias). Limnol. Oceanogr. 26: 414-423

Hofmann, D. K., Kremer, B. P. (1981). Carbon metabolism and strobilation in Cassiopea andromedea (Cnidaria: Scyphozoa): significance of endosymbiotic dinoflagellates. Mar. Biol. 65: 25-33

Huntley, M. E., Hobson, L. A. (1978). Medusa predation and plankton dynamics in a temperate fjord, British Columbia. J. Fish. Res. Bd Can. 35: 257-260

Kimmerer, W. J. (1987). The theory of secondary production calculations for continuously reproducing populations. Limnol. Oceanogr. 32: 1-13

Lindahl, O., Hernroth, L. (1983). Phyto-zooplankton community in coastal waters of western Sweden - an ecosystem off balance? Mar Ecol. Prog. Ser. 5: 119-126

Mayer, A. G. (1910). Medusae of the world. Vol. 3, The scyphomedusae. Carnegie Institution of Washington, Washington, D. C., p. 684

Möller, H. (1980). Population dynamics of Aurelia aurita medusae in Kiel Bight, Germany (FRG). Mar. Biol. 60: $123-128$

Möller, H. (1980b). Scyphomedusae as predators and lood competitors of larval fish. Meeresforsch. 28: 90-100

Muscatine, L., Marian. R. E. (1982). Dissolved inorganic nitrogen flux in symbiotic and nonsymbiotic medusae. Limnol. Oceanogr. $27 \cdot 910-917$

Muscatine. L. (1971). Endosymbiosis of algae and coelenterates. In: Lenhoff, H. M., Muscatme, L., Davis, L. V (eds.) Experimental coelenterate biology. Unıv. of Hawaii Press. Honolulu, p. 179-191 
Papathanassiou, E., Panayotidis, P., Anagnostaki, K. (1987). Notes on the biology and ecology of the jellyfish Aurelia aurita Lam. in Elefsis Bay (Sarinokos Gulf, Greece). P.S.Z.N. I: Mar Ecol. 8: 49-58

Pauly, D., Caddy, J.F. (1985). A modification of Bhattacharya's method for the analysis of mixtures of normal distributions. FAO Fish. Circ. 781 1-16

Purcell, J. E., Siferd, I D., Marliave, J. B. (1987). Vulnerability of larval herring (Clupea harrengus pallasi) to capture by the jellyfish Aequorea victoria. Mar. Biol. 94: $157-162$

Shapiro, S. S., Wilk, M. B., Chen, H. J. (1968). A comparative study of various tests for normality. J. Am. statist. Ass. 63: $1343-1372$

This article was submitted to the editor
Sokal, R. R., Rohlf, F. J. (1969). Biometry, 2nd edn. W. H. Freeman and Co., San Francisco

Van der Veer, H.W. Oorthuysen, W. (1985). Abundance, growth and food demand of the scyphomedusa Aurelia aurita in the western Wadden Sea. Neth. J. Sea Res. 19: 38-44

Yasuda, T (1971). Ecological studies of the jelly-fish, Aurelid aurita, in Urazoko Bay, Fukui Prefecture. IV. Monthly change in the bell-length composition and breeding season. Bull. Jap. Soc. scient. Fish. 37: 364-370

Yonge, C. M., Nicholls, A. G. (1931). Studies on the physiology of corals. IV The structure and physiology of zooxanthellae. Scient. Rep. Gi Barrier Reef Exped. 1928-29, Vol. 1, p. 135-176

Manuscript first received: November 6, 1989

Revised version accepted: April 4, 1990 